\title{
Site suitability analysis incorporating disease prediction in castor (Ricinus communis L.) production
}

\author{
Travis W. Witt ${ }^{1}$ (1) K. Colton Flynn ${ }^{2} \cdot$ Tiago Zoz $^{3} \cdot$ Eduardo B. A. Monteiro $^{4}$
}

Received: 2 April 2020 / Accepted: 28 September 2020 / Published online: 15 October 2020

(c) This is a U.S. Government work and not under copyright protection in the U.S.; foreign copyright protection may apply 2020

\begin{abstract}
Castor (Ricinus communis L.) is an important industrial crop used in the production of nylon, cosmetics, and many industrial lubricants. Currently, castor production in the USA has nearly ceased for $>45$ years, resulting in vast imports of castor oil to meet US demands. Renewed interest in this crop, especially the possibility of its use as a biolubricant, has increased the desire to learn more about where it can be produced. This study evaluated possible locations for castor production through site suitability analysis. This analysis determined potential sites for castor production by evaluating geospatial climatic, soils/geophysical, and disease data, the major drivers of castor growth and yields. The site suitability analysis determined that $12 \%$ of the contiguous USA is highly suitable for castor production. The state of Illinois has the highest percentage of arable land highly suitable for castor production (56\%/8 million ha). However, due to its large size, Texas has the most land area highly suitable for castor production ( 15 million ha). Validation of the site suitability analysis was obtained through ground-truthed data obtained from recent environmental studies testing various castor genotypes. For the southern USA $\left(<40^{\circ} \mathrm{N}\right.$ latitude), the regression analysis interested in site suitability point data versus performance (oil yield) at known growing sites resulted in a significant result $\left(R^{2}=0.46, p<0.01\right)$. Geospatial averaging site suitability values for $1-\mathrm{km}$ buffer of those growing sites further improved regression analysis $\left(R^{2}=0.57, p<0.01\right)$. T he findings of this study provide a method to perform site suitability for novel crops such as castor using data associated with agronomic and disease characteristics. Moreover, the analysis provides suggestion that castor could easily be reintroduced to US agricultural practices.
\end{abstract}

Keywords Site suitability analysis · Castor · Disease $\cdot$ Analytical hierarchy process (AHP) - Weighted overlay

\section{Introduction}

Castor (Ricinus communis L.) is a plant indigenous to eastern Africa, which has been cultivated since antiquity ( $>6,000$ years B.P.) due to its high oil production (38-60\% of weight) per seed [1]. The non-edible oil that castor produces is used in the production of nylon, cosmetics, and medicinal applications. In the USA and around the world, there is a renewed interest in castor due to its high oil production. This oil has great potential to be used as feedstock to produce biolubricants [2-4], especially with its ability to be grown on marginal lands $[5,6]$. Historically, the USA produced castor on 30,000 ha with yields in excess of 2,200 $\mathrm{kgha}^{-1}[7]$.

Although castor is relatively easy to grow, there are some major environmental limitations to its production in the USA. Some of the major environmental barriers to castor production are temperature, precipitation, soil type/characteristics, disease (especially Botryotinia ricini), and land cover [5, 7-11]. By determining where these

\footnotetext{
$\triangle$ Travis W. Witt, travis.witt@usda.gov; $\bowtie$ K.Colton Flynn, colton.flynn@usda.gov| ${ }^{1}$ Grazinglands Research Laboratory, USDA-ARS, PA, 7207 West Cheyenne Street, El Reno, OK 73036, USA. ${ }^{2}$ Grassland Soil and Water Research Laboratory, USDA-ARS, PA, 808 East Blackland Road, Temple, TX 76502, USA. ${ }^{3}$ Department of Crop Science, Mato Grosso do Sul State University, Mato Grosso do Sul, Cassilandia 79540-000, Brazil. ${ }^{4}$ EMBRAPA Informática Agropecuária, 209 André Tosello Street, Campinas, SP 13083-886, Brazil.
} 
factors will limit castor production, breeding efforts can be addressed to overcome these limitations.

Although castor was previously cultivated in the USA, only small adaptability studies have been conducted since 1945; many of the test locations in the 1945 studies suffered from gray mold [Botryotinia ricini (Godfrey) Whetzel], so the adaptability of castor in the USA is poorly understood $[10,12,13]$. By using a geographic information systems (GIS) approach, specifically a site suitability analysis, to determine castor production suitability, costly genotype $x$ environment $(G \times E)$ trials can be limited to study areas with drastically different environments. Site suitability analyses are systems of determining the possibility of using a specific piece of land for a specific purpose [14]. Within the US cotton belt, it was determined that many of the test locations for $G \times E$ studies were able to be put into mega-environments, thus limiting the number of locations needed to test interactions $[15,16]$. Site suitability analyses can help to identify these mega-environments, thus limiting the number of $G \times E$ trials that a plant breeder would need to evaluate. Site suitability analyses have been performed with good results in several crops such as tef in the USA and tea in India [17, 18]. But many of these studies lack emphasis on potential disease pressures as well as a validation set of data to produce an accuracy assessment of the site suitability analysis.

Therefore, the objectives of this study were to evaluate the suitability of environments throughout the USA to grow castor incorporating variables associated with disease pressure that may limit production. A secondary objective of this study is to confirm these findings based on existing castor trials obtained from the literature. By identifying different degrees of castor adaptability, breeding programs can better focus their evaluations and limit environmental effects through the use of more beneficial $\mathrm{G} \times \mathrm{E}$ trials.

\section{Materials and methods}

\subsection{Study area}

Castor production within the USA has been recorded in 28 states. However, production in many of these states was before the mechanization of agriculture (i.e., 1945) and information on adaptability, production acreage, and disease pressure was limited. Moreover, yield records are often missing and/or incomplete. The current study area consisted of the 48 contiguous USA ( $~ 808$ million ha) to determine where castor production can be revitalized. Furthermore, the diverse growing environments within these 48 states will optimize the suitability analysis and the analytical hierarchy process (AHP). The AHP was calculated based on rankings that were standardized and weighted (see Calculation of weights and map production section).

A thorough review of information on castor production around the world determined that castor production is influenced by the following criteria: average precipitation, average temperature, minimum temperature, soil $\mathrm{pH}$, soil texture (especially clay content), soil drainage, and disease pressure. In this study, disease pressure is an estimation of the likelihood of gray mold infestation of a castor field based on precipitation and temperature requirements for disease growth. The authors' experience with castor production and a review of current castor literature was used to determine the rankings of the criteria. The site suitability analysis was then validated using castor oil yield data $\left(\mathrm{kg} \mathrm{ha}^{-1}\right)$ of five castor genotypes grown at five different test environments during different years.

\subsection{Climatic data}

Castor which is native to tropical and subtropical regions of the world will require a certain amount of precipitation to produce adequate yields. However, castor has relatively high drought tolerance and is grown in many environments around the world where water is limited [5]. Castor requires between 188 and $897 \mathrm{~mm}$ of total water applied during the growing season $[10,19]$. In many environments, the majority of the applied water is through supplemental irrigation. This information provided the ranking of average precipitation sub-criteria for the AHP (Table 1). Castor requires a season length of approximately 140 to 180 days $[7,10]$, thus, establishing the season length (months above freezing) used for this study (Table 1). Castor requires a base temperature of $15.6^{\circ} \mathrm{C}$ for germination and plant growth, and harvest can occur 10 days after a killing frost [7]. The plant can survive a light freezing event at the end of the growing season [20]. However, 25 to $31{ }^{\circ} \mathrm{C}$ were determined to be the optimum temperatures for germination under most conditions [21]. In addition, the length of time for plant emergence could be shortened by 13 days by increasing the soil temperature from 10 to $19^{\circ} \mathrm{C}$ [22]. Castor growth flourishes under temperatures ranging from 20 to $30^{\circ} \mathrm{C}$, but temperatures in excess of $40^{\circ} \mathrm{C}$ can be detrimental to growth and yield. In addition, female flower production is reduced by temperatures in excess of $30^{\circ} \mathrm{C}$ (Severino et al., 2012). Furthermore, leaf growth is inhibited when soil temperatures are below $20^{\circ} \mathrm{C}$ [23]. Each of these studies provided the foundation for the sub-criteria rankings associated with temperature (e.g., average and minimum temperature) for the AHP (Table 1). To maximize the season length and limit data such as precipitation and temperature to the most important time of year, this study used the months of May to November as the growing season and, thus, data acquisition. 
Table 1 Rankings of each criterion for analytical hierarchy process (AHP) calculations from May 1 to November 30

\begin{tabular}{|c|c|c|}
\hline Main criteria & Sub-criteria & Ranking \\
\hline $\begin{array}{l}\text { Average precipitation }(\mathrm{mm}) \\
\text { May to November }\end{array}$ & $\begin{array}{l}>1000(>39.4 \mathrm{in}) \\
800-1000(31.5 \mathrm{in}-39.4 \mathrm{in}) \\
600-800(23.6 \mathrm{in}-31.5 \mathrm{in}) \\
400-600(15.7 \mathrm{in}-23.6 \mathrm{in}) \\
200-400(7.9 \mathrm{in}-15.7 \mathrm{in}) \\
<200(<7.9 \mathrm{in})\end{array}$ & $\begin{array}{l}8 \\
10 \\
8 \\
7 \\
5 \\
1\end{array}$ \\
\hline $\begin{array}{l}\text { Average temperature }\left({ }^{\circ} \mathrm{C}\right) \\
\text { May to November }\end{array}$ & $\begin{array}{l}20-30 \\
>30 \\
16-20 \\
<16\end{array}$ & $\begin{array}{l}10 \\
7 \\
5 \\
1\end{array}$ \\
\hline $\begin{array}{l}\text { Minimum temperature } \\
\text { May to November }\end{array}$ & $\begin{array}{l}6-7 \text { months above freezing } \\
5-6 \text { months above freezing } \\
4-5 \text { months above freezing } \\
4 \text { or less months above freezing }\end{array}$ & $\begin{array}{l}10 \\
8 \\
6 \\
1\end{array}$ \\
\hline Soil pH & $\begin{array}{l}5-8 \\
8-10 \\
4-5 \\
<4\end{array}$ & $\begin{array}{l}10 \\
7 \\
5 \\
1\end{array}$ \\
\hline Soil texture (\% Clay) & $\begin{array}{l}15-25 \\
25-40 \\
40-50 \\
<15 \\
>50\end{array}$ & $\begin{array}{l}10 \\
8 \\
6 \\
2 \\
1\end{array}$ \\
\hline Soil drainage & $\begin{array}{l}\text { Excessive } \\
\text { Somewhat excessively } \\
\text { Well or moderately well } \\
\text { Somewhat poorly } \\
\text { Poorly }\end{array}$ & $\begin{array}{l}2 \\
4 \\
10 \\
4 \\
1\end{array}$ \\
\hline \# of rainy days (disease prone) & $\begin{array}{l}<30 \\
30-60 \\
60-75 \\
75-90 \\
90-105 \\
105-120 \\
120-135 \\
135-150 \\
>150\end{array}$ & $\begin{array}{l}10 \\
8 \\
7 \\
6 \\
5 \\
4 \\
3 \\
2 \\
1\end{array}$ \\
\hline Temperature $\left({ }^{\circ} \mathrm{C}\right)$ (disease prone) & $\begin{array}{l}15-20 \\
20-25 \\
25-35,<15\end{array}$ & $\begin{array}{l}10 \\
3 \\
1\end{array}$ \\
\hline Land cover & $\begin{array}{l}71,72,81,82 \\
\text { Other categories }\end{array}$ & $\begin{array}{l}10 \\
1\end{array}$ \\
\hline
\end{tabular}

\subsection{Soils and geophysical data}

After climatic requirements, soil requirements are the most important factor in castor production. One factor that may limit castor production is soil $\mathrm{pH}$, although it can easily be corrected; it may reduce the profitability of castor production. Soil pH is important for nutrient availability and nutrient toxicity [24]. Castor requires a pH of 5 to 8 [25]. Furthermore, the soil texture helps to determine nutrient availability, water holding capacity, and drainage. Castor grows best in a sandy loam to loam soil [25]. One reason that castor grows best on these soils is because they are well drained, which castor needs $[10,11]$. Also, castor has a high oxygen requirement and its root system is sensitive to hypoxia [26]. In addition to the other soil conditions, land use capability classes can be used to predict where a crop can grow. These classes range from class 1 to 8 (best to worst) based on soil erosion, flooding, soil depth, etc. [24]. These studies helped to determine the sub-criteria rankings for the soil and geophysical data (i.e., soil pH, soil texture, soil drainage, and land coverage).

\subsection{Disease pressure}

If castor has favorable growing conditions, then gray mold will be the main limitation to castor production. Gray mold was first reported in the USA in 1918 and has been known to limit castor production globally $[8,10]$. As reviewed by 
Soares, 2012 , gray mold appears most often at temperatures ranging from 14.6 to $28^{\circ} \mathrm{C}\left(25-28^{\circ} \mathrm{C}\right.$ is optimal). The same author also noted that leaf wetness of at least six hours encouraged gray mold growth; however, $72 \mathrm{~h}$ is optimal, and that rainfall is more important than humidity to predict gray mold incidence. Although there are many factors that contribute to gray mold, these studies helped us to determine the sub-criteria rankings for the disease to occur (i.e., number of rainy days and temperature).

\subsection{Calculation of weights and map production}

The AHP is a decision-making process using relative significance of criteria in pairs $[27,28]$. The significance of the criteria, in this case on castor production, is ranked from 1 to 9 (least important to most important) (Table 2; see Flynn 2019 for more detail). Saaty (1980) suggested that these rankings should be based on the authors' experience with a crop, previous studies, and/or a panel of professionals. These rankings are then used to give the factors in the comparison matrix their normalized weights based on significance (Table 3; see Flynn 2019 for more detail). These weights require the use of a random consistency index (RI), a consistency index $(\mathrm{Cl})$, the number of criteria incorporated in the study $(n=9)$, and the calculated consistency ratio (CR). The $C R$ value must be less than 0.10 to ensure there are no inconsistencies in the calculation of the weights $[17,27]$. After the weights were calculated, they were used to calculate the sum of the products of the sub-criteria rankings by the calculated weights for each criterion for each pixel $(90 \mathrm{~m} \times 90 \mathrm{~m})$ of the contiguous USA. For each pixel, the sum of the products would range from values of 1 (low suitability) to 10 (high suitability). To categorize the suitability levels, the Food and Agriculture Organization of the United Nations (FAO) classifications of suitability was employed: (1) highly suitable [10-8], (2) moderately suitable [8-6], (3) marginally suitable [6-4],
(4) currently not suitable [4-2], and (5) permanently not suitable $[<2][17,29]$. Rendering this raster geospatially determines where in the USA it is most suitable for castor production. The combining of the raster layers was conducted in ArcGIS 10.3 utilizing the raster calculator data management tool (ESRI, Redlands, CA).

Data were retrieved and analyzed for individual yearly data (2011-2013) to test the model as the castor trials took place during these years. Additionally, 30-year average data (1981-2018) were used to predict castor production on a long-term basis in the USA. Precipitation data for the USA (single-year and 30-year average data) were obtained from the Prism Climate Group at $800 \mathrm{~m}$ resolution and were gridded to $90 \mathrm{~m}$ to match the resolution of other datasets. The average precipitation values were then standardized for the weighted overlay and AHP. In addition, the soil type, $\mathrm{pH}$, drainage, and suitability were obtained from Web Soil Survey [30] and they were also transformed into a $90 \mathrm{~m}$ resolution raster based on soil boundaries. Due to the slow pace that soil data change, the same data were used for both the yearly analysis and 30-year predictions. The soil measurements were from the surface to one meter. Temperature data were based on single-year and 30-year averages and utilized in the corresponding analysis. Similar to the other data used, it was obtained at $800 \mathrm{~m}$ resolution and gridded to $90 \mathrm{~m}$ to match the resolution of the other datasets.

\subsection{Accuracy assessment analysis}

To conduct an accuracy assessment, dependent and independent data were analyzed using the Reg procedure in SAS 9.4 [31]. Analysis was performed on the oil yield (kg $\mathrm{ha}^{-1}$ ) data (dependent variable) obtained from a previous study [12]. These yield data were compared to the site suitability values (independent variables) of the specific geographic coordinates $\left(X_{1}\right)$ and averaged site suitability

Table 2 Pairwise comparison matrix

\begin{tabular}{|c|c|c|c|c|c|c|c|c|c|}
\hline 1 & Soil texture & Soil drainage & Soil pH & Average temp & $\begin{array}{l}\text { Mini- } \\
\text { mum } \\
\text { temp }\end{array}$ & Precip & Disease temp & Disease precip & Land cover \\
\hline Soil texture & 1 & 1 & 1 & 3 & 3 & 4 & 6 & 6 & 9 \\
\hline Soil drainage & 1 & 1 & 1 & 3 & 3 & 3 & 6 & 6 & 9 \\
\hline Soil pH & 1 & 1 & 1 & 3 & 3 & 4 & 6 & 6 & 9 \\
\hline Average temp & $1 / 3$ & $1 / 3$ & $1 / 3$ & 1 & 1 & 4 & 4 & 4 & 9 \\
\hline Minimum temp & $1 / 3$ & $1 / 3$ & $1 / 3$ & 1 & 1 & 4 & 4 & 4 & 9 \\
\hline Precip & $1 / 4$ & $1 / 3$ & $1 / 4$ & $1 / 4$ & $1 / 4$ & 1 & 4 & 4 & 9 \\
\hline Disease temp & $1 / 6$ & $1 / 6$ & $1 / 6$ & $1 / 4$ & $1 / 4$ & $1 / 4$ & 1 & 1 & 9 \\
\hline Disease precip & $1 / 6$ & $1 / 6$ & $1 / 6$ & $1 / 4$ & $1 / 4$ & $1 / 4$ & 1 & 1 & 9 \\
\hline Land cover & $1 / 9$ & $1 / 9$ & $1 / 9$ & $1 / 9$ & $1 / 9$ & $1 / 9$ & $1 / 9$ & $1 / 9$ & 1 \\
\hline
\end{tabular}




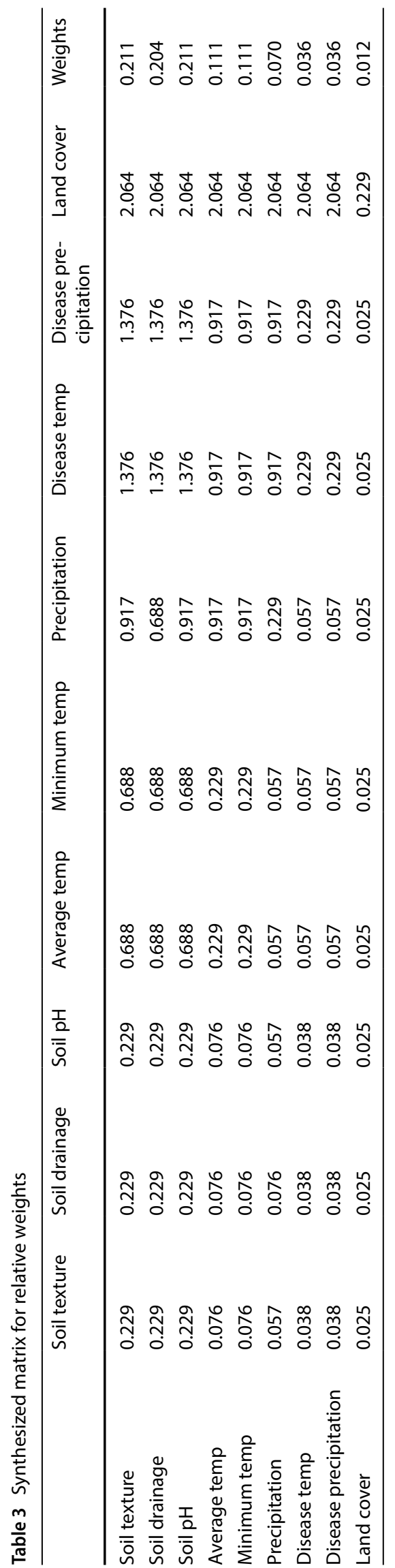

values of a one-kilometer radius from those same coordinates $\left(X_{2}\right)$. For all statistical analyses, effects were declared significant at the 0.05 probability level. Prior to analysis, yield data were log transformed and site suitability of the point and one-kilometer radius were arcsine square root transformed to normalize the data.

\section{Results}

\subsection{Climatic data}

For the climatic data, the average precipitation varied greatly between the three years, 2013 had the most favorable precipitation across the USA, while 2012 had the least favorable conditions (Fig. 1). For the thirty-year average data, $21 \%$ of the USA had a ranking of 10 for the average precipitation and $9 \%$ had a ranking of 1 (Fig. 2). The average temperatures of 2011 and 2012 (32\% highly suitable) were more favorable to castor production than 2013 (27\%) (Fig. 1). For the 30-year average, more hectares had an average temperature unfavorable (permanently not suitable) to castor production and then favorable (highly suitable) $45 \%$ and $29 \%$, respectively (Fig. 2). The minimum temperature of the three years appeared to be relatively unchanged for the months of May through November. The highly suitable area ranged from $62 \%$ for 2012 to $57 \%$ in 2013. The 30-year average had a highly suitable area of $61 \%$ of the total USA (Fig. 1).

\subsection{Soils and geophysical data}

Physical geography data for the traits evaluated do not change yearly, so only 30-year average data are reported (Fig. 2). The majority of the USA (67\%) has a pH highly suitable for castor production, and $6 \%$ has a $\mathrm{pH}$ permanently unsuitable for castor production. For land cover, $37 \%$ of the USA is highly suitable and $60 \%$ is permanently unsuitable. For soil drainage, $12 \%$ of the USA has highly suitable soil drainage and $8 \%$ does not have the soil drainage (permanently unsuitable) required for castor production. Approximately, one quarter of the USA (26\%) has the clay content required to produce castor (highly suitable) and $3 \%$ is highly unsuitable for castor production (permanently unsuitable).

\subsection{Disease pressure}

Gray mold occurs when both precipitation and temperature are favorable for its growth, so disease ratings are based on the ability to avoid the disease in each location (i.e., a 10 would indicate a low probability of disease). For 2011 to 2013, the area that would have had 
Fig. 1 Suitability maps for each annually changing criterion. Light areas represent low suitability (1) and dark areas represent high suitability (10) for each criterion

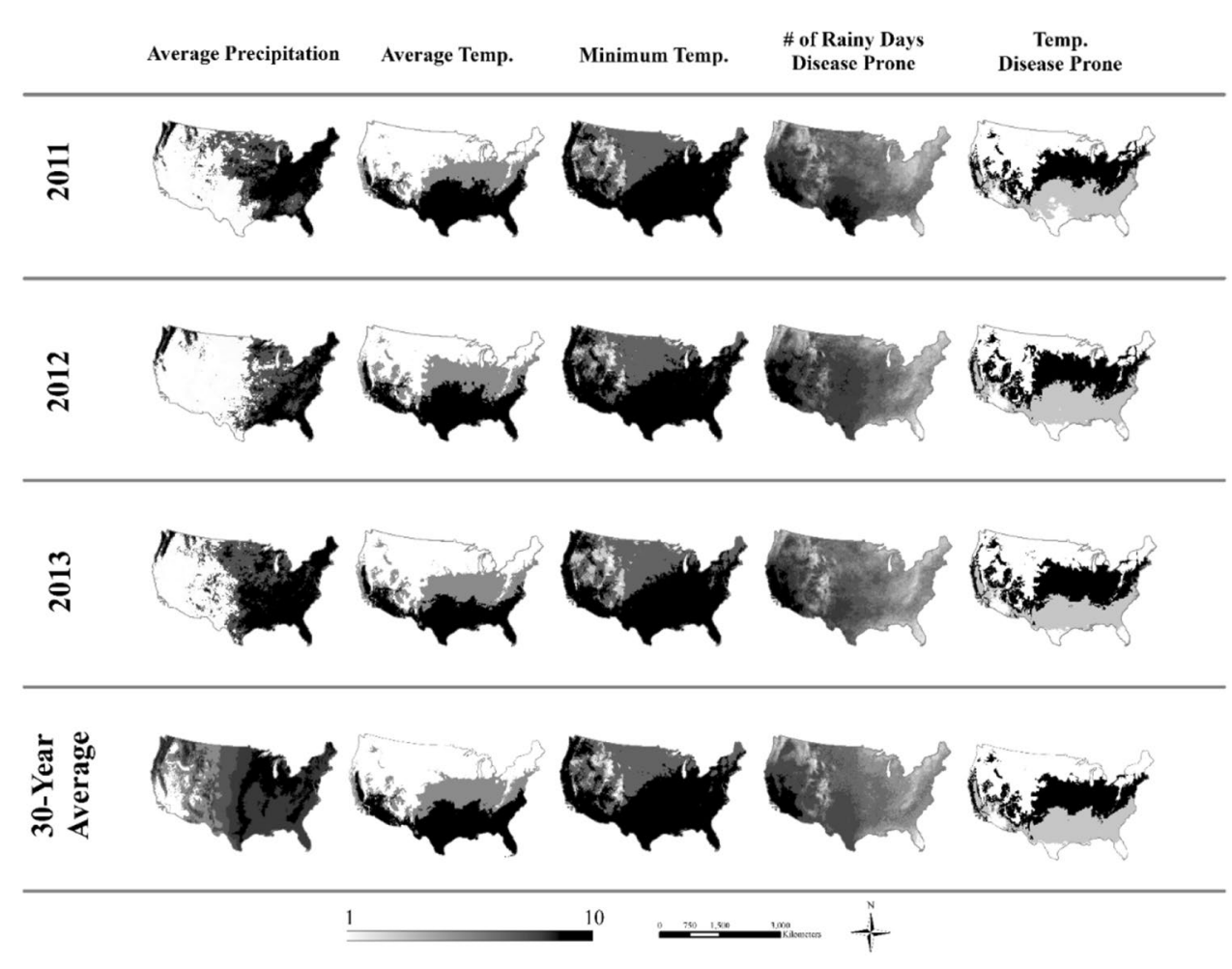

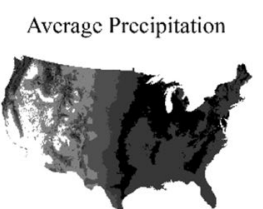
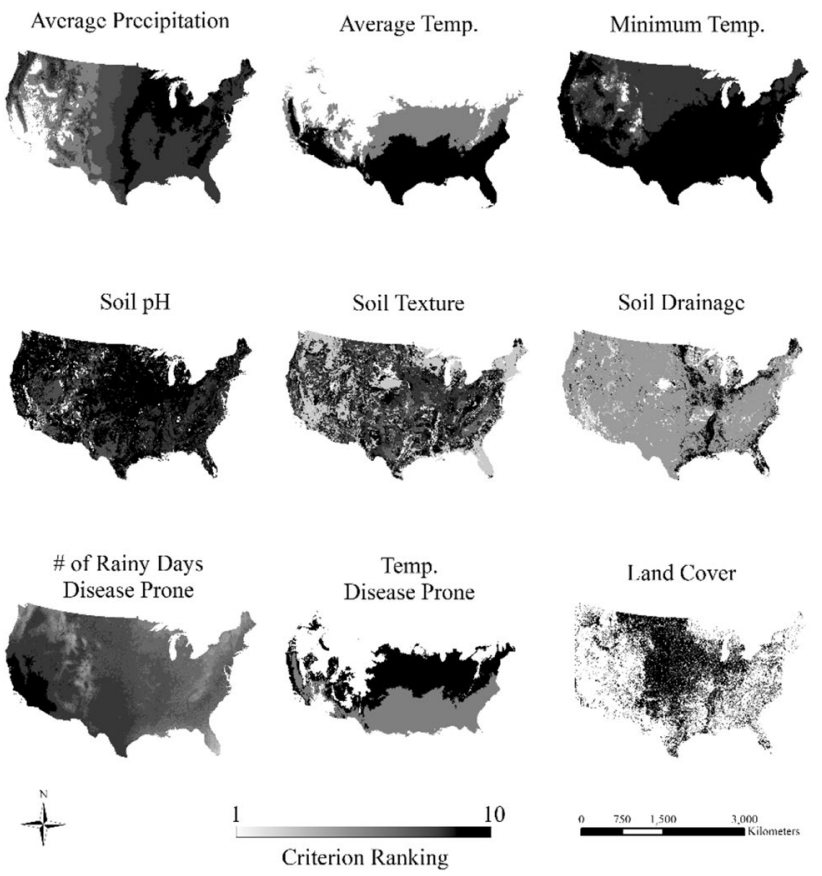

Fig. 2 Average 30-year suitability maps for each criterion. Light areas represent low suitability (1) and dark areas represent high suitability (10) for each criterion

the least precipitation needed for disease ranged from $11 \%$ (highly suitable for no disease growth) in 2011 to
$6 \%$ (highly suitable for no disease growth) of the US hectares in 2013 (Fig. 3). In 2011, the most favorable areas to avoid the precipitation needed for disease were the southern and western USA. In 2012, although the area of highly favorable areas had decreased, the favorable area had spread into the Great Plains region of the USA. In 2013, rainfall increased over the study area and fewer places were suitable to avoid disease. For the 30-year average, $6 \%$ of the USA (highly suitable for disease avoidance) would lack the precipitation needed for disease (Fig. 1). Over all three years, less than $1 \%$ of the USA would have the rainfall to consistently foster gray mold growth (permanently unsuitable for disease avoidance) (Fig. 3). For the temperature needed to avoid gray mold, there was a 30 -year average of $0.36 \%$ area (highly suitable for disease avoidance) (Fig. 1). However, there was only a $0.46 \%$ area that was highly likely to have the temperature required for disease growth (permanently unsuitable for disease avoidance). During the 20112013 growing seasons, there was a $0.39 \%$ area of the USA where the temperature was not suitable for gray mold (highly suitable for disease avoidance) $(2012,2013)$ and $0.34 \%$ area for 2012 (Fig. 3). However, disease was most likely in 2011 (0.45\%) and least likely in 2012 (0.37\%). In all three years, the midwestern USA was less likely to have disease based on average temperatures. However, the western USA was less likely to be suitable for gray mold based on precipitation. 
Percent of state suitable for castor production

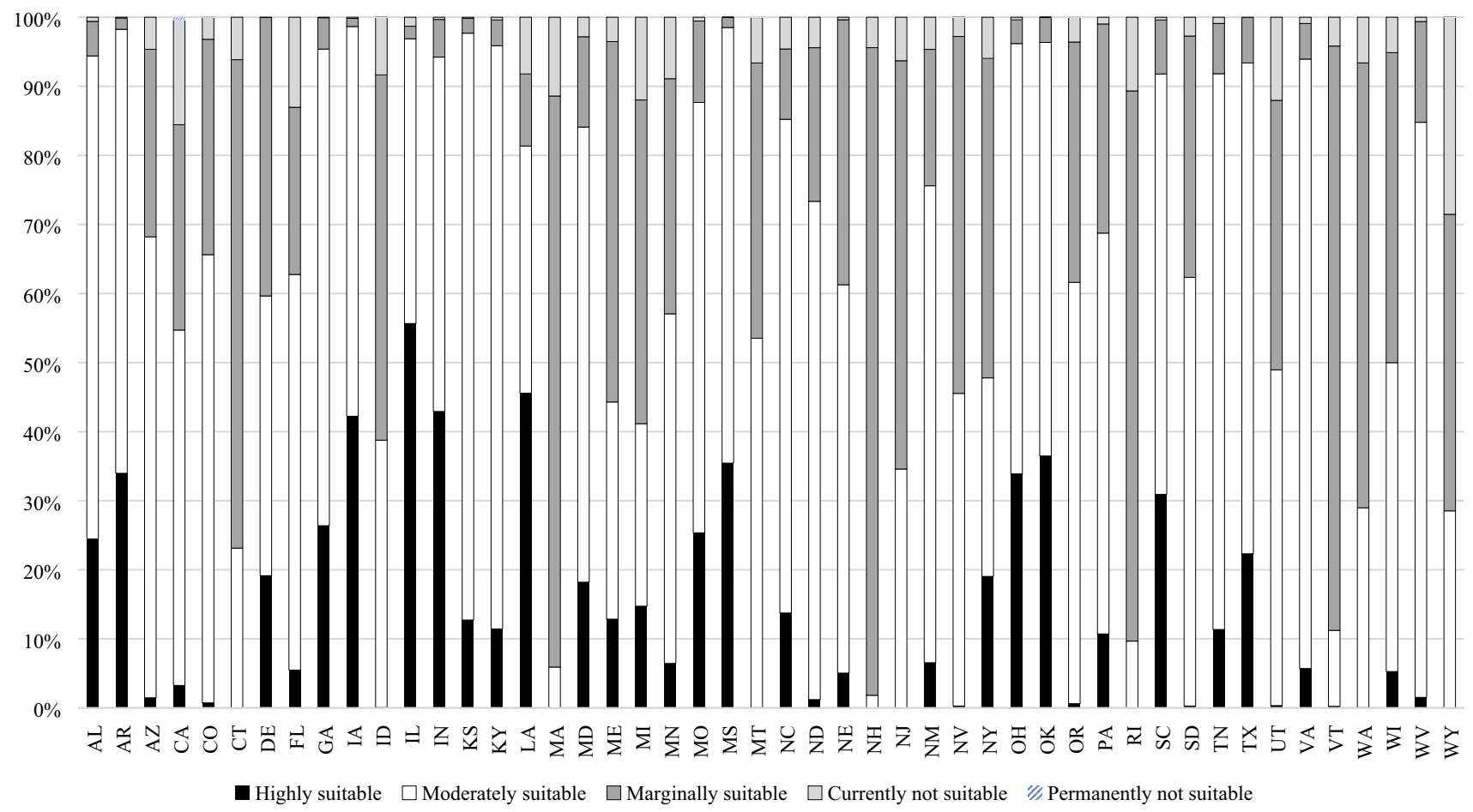

Fig. 3 Percent area of varying suitability levels for castor production by individual states within the contiguous USA based on 30-year averages

\subsection{Accuracy Assessment}

For the areas that were used for validation, Lubbock, TX, had the highest point suitability $\left(X_{1}\right)(7.7)$ and Kinderhook, NY, had the lowest suitability (5.2) [Fig. 4]. For the one-kilometer radius suitability $\left(X_{2}\right)$, again, Lubbock, TX, had the highest suitability (7.7) and Kinderhook, NY, had the lowest (5.2). The analysis performed well at the southern latitudes and poorly at the more northern latitudes. For the southern latitudes (those below 40 degrees north latitude; Texas and Florida), the analysis performed well $\left(R^{2}=0.46\right.$, $p<0.01)$ at known test locations/growing sites $\left(X_{1}\right)$ and was better $\left(R^{2}=0.57, p<0.01\right)$ for the geospatially averaged site suitability 1 -km buffer zones $\left(X_{2}\right)$ (Fig. 4), while in the northern environments (North Dakota and New York), the analysis performed poorly $\left(R^{2}=0.01, p=0.74\right)$ for the specific test locations $\left(X_{1}\right)$ and the 1-km buffer zones $\left(X_{2}\right)$ $\left(R^{2}=0.01, p=0.76\right)$. The accuracy of the model in the southern USA could lead to the identification of areas to grow castor, in this area of the USA.

\subsection{National-Level Site Suitability}

The contiguous USA is a relatively large country with over 808 million ha of land of that the total area $12 \%$ is highly suitable (Fig. 5). Illinois has the greatest percent of area highly suitable (56\%/8 million ha; Fig. 3). Fifteen US states all have less than $1 \%$ of their area that is highly suitable for castor production (Fig. 3). Texas had the most total area highly suitable for castor production ( 15.3 million ha). Seven US states have permanently not suitable land for castor production. However, this is less than $0.4 \%$ of these states' total area.

\section{Discussion}

Castor production in the USA ceased after the 1970s; however, a large part of the USA is capable of producing this crop. This study focused on creating a model for castor production based on the performance of five genotypes at five different test environments across different years. The southwestern part of the USA would be an ideal place to grow castor, because there is a low chance of having enough consecutive days of rainfall to encourage the growth of gray mold. However, supplemental irrigation would probably be needed for growth of the plant. The eastern and southeastern USA would have a high probability of gray mold based on rainfall and temperature. 

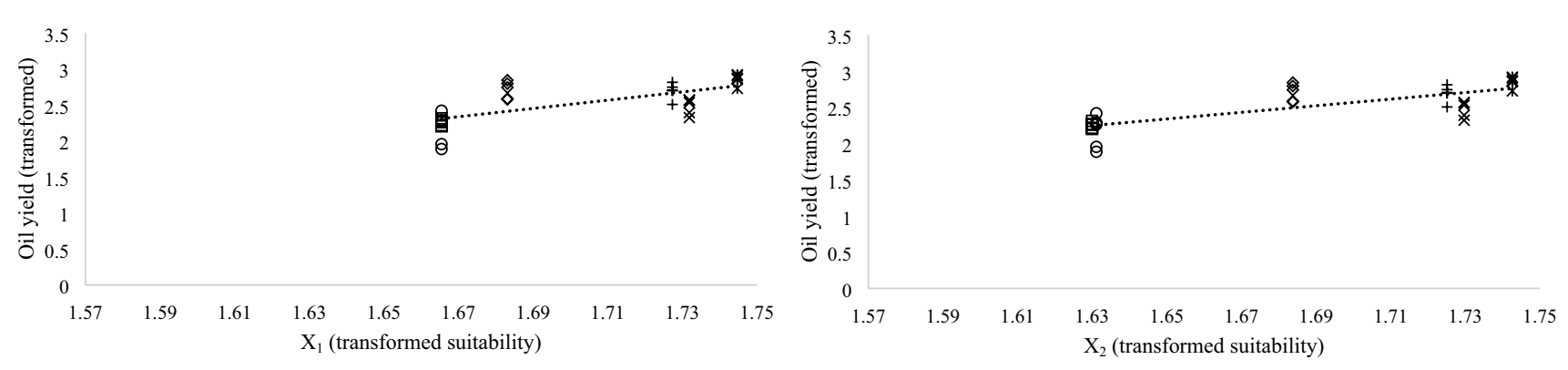

OFlorida $2011 \quad \square$ Florida $2012 \quad \times$ Lubbock 2011

+Lubbock 2012 * Lubbock $2013 \diamond$ Pecos 2012

OFlorida $2011 \quad \square$ Florida $2012 \quad \times$ Lubbock 2011

+ Lubbock 2012 X Lubbock $2013 \diamond$ Pecos 2012
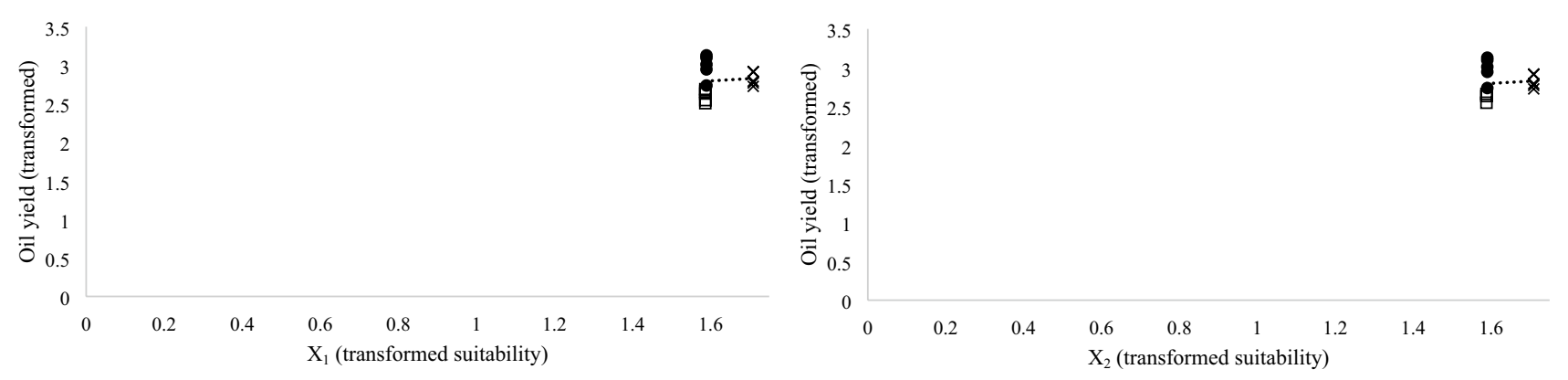

$\square$ New York 2011 New York 2012 XNorth Dakota 2012

$\square$ New York 2011 New York 2012 × North Dakota 2012

Fig. 4 Accuracy assessment of point and 1-km site suitability analysis of oil yield of five castor genotypes in the southern $\left(<40^{\circ} \mathrm{N}\right)$ and northern $\left(>40^{\circ} \mathrm{N}\right)$ USA

Fig. 5 Site suitability (30-year average) of the contiguous USA

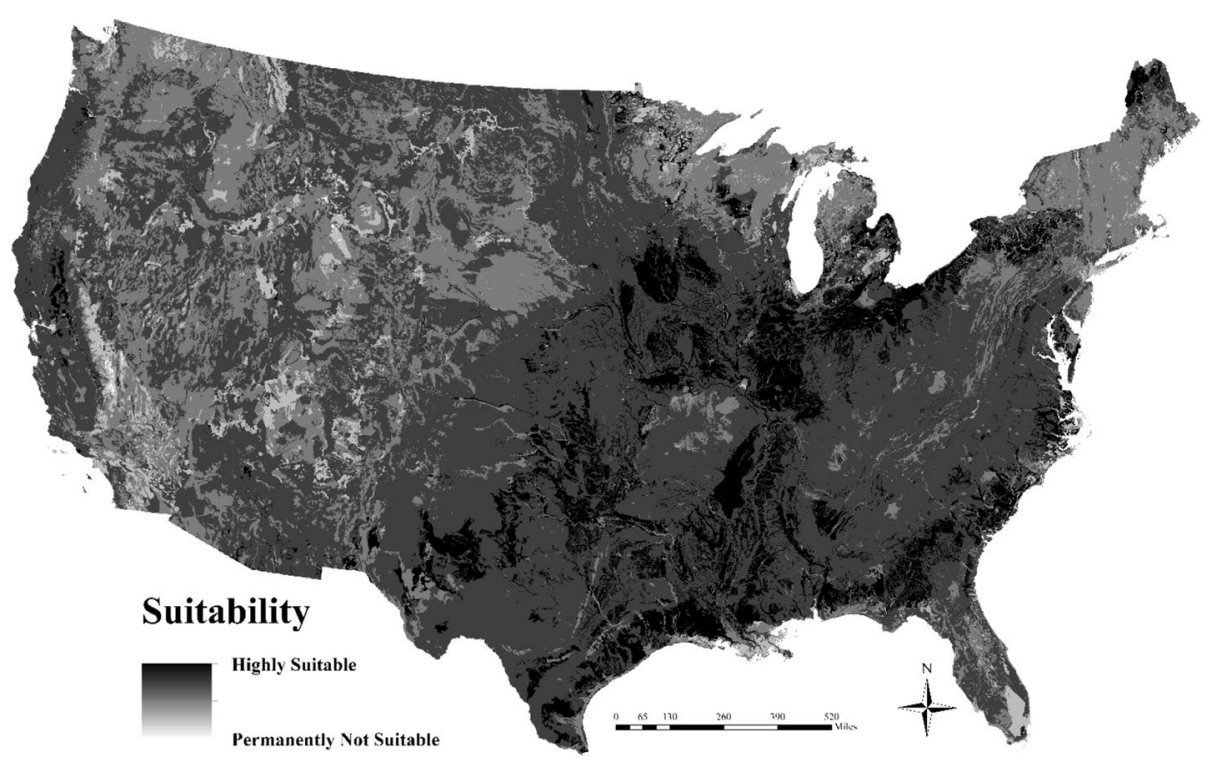

For the USA, castor production appears to be most limited by the number of days with consecutive rainfall. This consecutive rainfall could encourage gray mold growth [8]. The threat of gray mold suggests that only $6 \%$ of the area is highly suitable for castor production. This area, 48 million ha, is a much larger area than the 30,000 ha previously used for castor production in the
USA [7]. However, because castor is only an industrial crop, many of the $\sim 48$ million ha may currently be used by more important food crops. The least limiting factor for castor production was minimum temperature. Only $1 \%$ ( 9 million ha) of the USA would not have enough days above freezing ( $>140$ days required) for adequate castor production [7, 32].

\section{SN Applied Sciences}


Unlike other site suitability analysis studies on castor [33] and other AHP-based studies [18, 27], this study focused on validating the model based on $G \times E$ studies from across the area of interest. For the southern USA, the model was highly predictive of castor oil yield. This may be due to the higher consistency in the traits of average temperature and minimum temperature. The minimum temperature would be important for germination and season length $[7,10]$. The high suitability for the southern USA, especially Lubbock, TX, was expected, because the center of castor production in the 1970s was Plainview, TX, which is $\sim 75 \mathrm{~km}$ north of Lubbock [7, 34]. Many areas of the western USA may be ideal to produce castor with supplemental irrigation. Domingo and Crooks (1945) reported seed yields of $2,392 \mathrm{~kg} \mathrm{ha}^{-1}$ to $974 \mathrm{~kg} \mathrm{ha}^{-1}$ in the state of Arizona. In the current study, $68 \%$ of Arizona was either highly or moderately suitable for castor production.

The model's performance indicates poor prediction of oil yield in the northern USA. This may be due to several factors. The first factor is the number of genotypes used in this study for validation of the model. Of the five genotypes, only Hale has been commercially grown in the USA. Domingo and Crooks (1945) showed that of the 15 genotypes that they evaluated over multiple locations from 1941 to 1943 , the yields varied widely from $1119 \mathrm{~kg} \mathrm{ha}^{-1}$ for Arlington to $66 \mathrm{~kg} \mathrm{ha}^{-1}$ for Woburn. The accuracy of the model could have been improved by using one genotype at all locations. However, the robustness of the model would suffer. When evaluating the leaf area of rose genotypes grown at several different locations, it was discovered that the accuracy of the model could be greatly improved by adding genotypic information [35]. According to Witt (2014), the five castor genotypes evaluated in this study behaved very differently in the northern and southern USA. He noted that at the northern latitudes, the castor cultivars produced double the seed yield $(\mathrm{kg}$ $\mathrm{ha}^{-1}$ ) that they produced at the southern latitudes. This is probably due to temperatures greater than $40^{\circ} \mathrm{C} \mathrm{lim}$ iting female flower production in the southern environments [19]. In the current study, Illinois had the highest percent of the state that was highly suitable. However, at the northern latitudes, some castor genotypes may be more photoperiodic [13]. Within the site suitability analysis, the average temperatures during the three years varied widely for much of the northern USA. This would affect the consistency of yields obtained in northern environments. Although the model poorly predicted oil yield for the northern USA, there may be potential to grow castor in this area. However, based on temperature, rainfall, and the threat of gray mold it is not recommended $[7,8,10]$. Gray mold has been shown to result in $100 \%$ of stand losses [36]. The site suitability was higher in 2011 and 2012 for Kinderhook, NY, than the 30-year average (Fig. 4). This suggests that during certain years, castor production may be favorable in the northern USA; however, for long term it would not be recommended. The yields at Kinderhook may have been higher than expected, because disease was not detected during this study. However, long-term production of castor in the same area may increase the likelihood of gray mold occurrences.

For the first time in an AHP-based site suitability analysis, disease prediction was included in the model. The disease prediction in the current study helped to make the site suitability analysis more beneficial to plant breeders, plant pathologists, and other scientists. Disease detection is one of the most desirable tasks for predictive modelling as diseases annually cause the loss of $10 \%$ of crops globally $[37,38]$. Predicting disease will create a site suitability map with a more accurate representation of where castor can be grown in the USA and strengthens the AHP analysis compared to past methods of site suitability not accounting for disease variables. Predicting disease is important for a novel crop, such as castor, because infrastructure will need to be created or repurposed for harvest, storage, processing, and transportation of the crop.

\section{Conclusion}

This study aimed to combine disease forecasting with agronomic variables to determine where in the US castor production could return. The site suitability model was predictive of castor yield in the southern USA $\left(R^{2}=0.46\right)$ and less accurate in the northern USA. The site suitability analysis performed identified days of consecutive rainfall as the most important trait for castor production, because it determines the likelihood of gray mold. The number of days above freezing was the least important variable in this study. Of the test locations used to validate the model, Lubbock, TX, had the highest suitability. This location is $\sim 75 \mathrm{~km}$ from where castor production was centered when it ceased in the USA. The site suitability analysis performed in the current study could help producers or scientists find places for castor production in the USA or limit the necessity of $\mathrm{G} \times \mathrm{E}$ trials. Further castor studies can be used to determine the confounding variables reducing the accuracy of the model in the northern USA. Although this site suitability study attempted to define a baseline for US castor production, we acknowledge that fungicides, breeding/ genetics, and agronomic practices may be able to limit the likelihood of gray mold thus drastically changing the areas that would be suitable for castor production. In addition, further studies may uncover the confounding factors of why the suitability analysis performed poorly in the northern USA. Also, further studies are needed 
to determine the profitability of growing castor and the expenses associated with it (i.e., lime, fertilizers, pesticides, etc.).

Acknowledgements Mention of trade names or commercial products in this article is solely for the purpose of providing specific information and does not imply recommendation or endorsement by the US Department of Agriculture. The US Department of Agriculture is an equal opportunity provider and employer.

Funding Funding was provided by USDA-ARS (Project 3070-31630019-00-D) (TW).

\section{Complaince with ethical standards}

Conflict of interest On behalf of all authors, there are no conflicts of interest.

\section{References}

1. Atsmon D (1989) Castor. In: Robbelen G, Downey RK, Ashri A (eds) Oil crops of the world. McGraw-Hill, New York, NY, pp 438-447

2. Rios IC et al (2019) Chemical modification of castor oil fatty acids (Ricinus communis) for biolubricant applications: An alternative for Brazil's green market. Ind. Crops Prod. 145(2020):112000

3. da Silva JAC, Soares VF, Fernandez-Lafuente R, Habert AC, Freire DMG (2015) Enzymatic production and characterization of potential biolubricants from castor bean biodiesel. J. Mol. Catal. B Enzym. 122:323-329

4. Hajar M, Vahabzadeh F (2014) Artificial neural network modeling of biolubricant production using Novozym 435 and castor oil substrate. Ind Crops Prod 52:430-438

5. Severino LS et al (2012) A review on the challenges for increased production of castor. Agron J 104(4):853-880

6. Auld DL, Zanotto MD, McKeon T, Morris JB (2010) Castor. Springer, New York, New York

7. Brigham RD (1993) Castor: Return of an old crop. In: Janick J, Simon JE (eds) New Crops. Wiley, New York, pp 380-383

8. Soares DJ (2012) The gray mold of castorbean: a review. In: Cumagun CJR (ed) Plant Pathology. InTech Publisher, Rijeka Croatia, pp 219-240

9. Severino LS, Auld DL (2013a) A framework for the study of the growth and development of castor plant. Ind Crops Prod 46:25-38

10. Domingo WE, Crooks DM (1945a) Investigations with the castor bean plant: I. adaptation and variety tests1. J Am Soc Agro. 37(9):750

11. Lopes GEM, Vieria HD, Partelli FL (2014) Evaluation of castor bean genotypes sown in winter and summer at a low altitude. Genet Mol Res 13(4):8807-8814

12. Witt TW (2014) Performance of Five Castor (Ricinus communis L.) Genotypes in Geographically Diverse Environments of North America. Texas Tech University, Lubbock

13. Baldwin BS, Cossar RD (2009) Castor yield in response to planting date at four locations in the south-central united states. Ind Crops Prod 29(2-3):316-319

14. Bandyopadhyay S, Jaiswal RK, Hegde VS, Jayaraman V (2009) Assessment of land suitability potentials for agriculture using a remote sensing and GIS based approach. Int J Remote Sens 30(4):879-895

15. Campbell BT, Jones MA (2005) Assessment of genotype X environment interactions for yield and fiber quality in cotton performance trials. Euphytica 144(1-2):69-78
16. Zeng L et al (2014) Genotype-by-environment interaction effects on lint yield of cotton cultivars across major regions in the U.S. cotton belt. Cott Sci 84(18):75-84

17. Flynn KC (2019) Site suitability analysis for tef (Eragrostis tef) within the contiguous United States. Comput Electron Agric 159(February):119-128

18. Pramanik MK (2016) Site suitability analysis for agricultural land use of Darjeeling district using AHP and GIS techniques. Model Earth Syst Environ. 2(2):56

19. Severino LS (2012) Studies on yield components and seed physiology of castor (Ricinus communis L.). Texas Tech University, Lubbock

20. Severino LS, Auld DL (2014) Study on the effect of air temperature on seed development and determination of the base temperature for seed growth in castor (Ricinus communis L.). Aust J Crop Sci 8(2):290-295

21. Moshkin VA (1986) Castor. Amerind, New Delhi

22. Weiss EA (2000) Oilseed Crops, 2nd edn. Blackwell Science, Oxford

23. Poiré $R$, Schneider $H$, Thorpe MR, Kuhn AJ, Schurr U, Walter $A$ (2010) Root cooling strongly affects diel leaf growth dynamics, water and carbohydrate relations in Ricinus communis. Plant, Cell Environ 33(3):408-417

24. Weil RR, Brady NC (2017) The Nature and Properties of Soils, 15th Edition, 15th edn. Macmillan Publishing Company, London

25. Martin JH (1957) Field Crops. Yearbook of Agriculture - 1957. Washington D. C, The United States Government Printing Office, pp 663-665

26. Severino LS, Auld DL (2013b) A framework for the study of the growth and development of castor plant. Ind Crop Prod 46:25-38

27. Saaty TL (1980) The Analytic Hierarchy Process: Planning, Priority Setting, Resource Allocation. McGraw-Hill International, New York

28. Miller W, Collins MG, Steiner FR, Cook E (1998) An approach for greenway suitability analysis. Landsc Urban Plan 42(2-4):91-105

29. FAO 1976 "Chapter 3 : Land suitability classifications," in A framework for land evaluation. Soils Bulletin 32: Food and Agriculture Organization of the United Nations, Rome, Italy

30. U. S. D. of 2019 Soil Survey Staff, Natural Resources Conservation Service, "Web Soil Survey," [Online]. Available: https://websoilsur vey.sc.egov.usda.gov/.

31. SAS Institute Inc (2013) SAS/STAT" 13.1 User's Guide. Cary, NC

32. Domingo WE, Crooks DM (1945b) Investigations with the CastorBean Plant: II. Rate-of-planting and date-of-planting tests1. Agron. J. 37(10):812

33. Falasca SL, Ulberich AC, Ulberich E (2012) Developing an agroclimatic zoning model to determine potential production areas for castor bean (Ricinus communis L.). Ind Crops Prod 40(1):185-191

34. Brigham RD, Spears BR (1969) Castor beans in Texas. Wiley, New York, pp 380-383

35. Gao M, Van der Heijden GWAM, Vos J, Eveleens BA, Marcelis LFM (2012) Estimation of leaf area for large scale phenotyping and modeling of rose genotypes. Sci Hortic (Amsterdam) 138:227-234

36. Godfrey GH (1923) Gray mold of castor bean. J Agric Res 23(9):679-715

37. Liakos KG, Busato P, Moshou D, Pearson S, Bochtis D (2018) Machine learning in agriculture: a review. Sensors (Switzerland) 18(8):1-29

38. Strange RN, Scott PR (2005) Plant disease: a threat to global food security. Annu Rev Phytopathol 43(1):83-116

Publisher's Note Springer Nature remains neutral with regard to jurisdictional claims in published maps and institutional affiliations. 